Open Access

\title{
The single farm payment and income risk in Irish farms 2005-2013
}

\author{
Edward Knapp ${ }^{*}$ (D) and Jason Loughrey
}

\author{
* Correspondence: \\ Edward.Knapp@Teagasc.ie \\ Agricultural Economics and Farm \\ Survey Department, Rural Economy \\ and Development Programme, \\ Teagasc, Athenry, Ireland
}

\begin{abstract}
Agricultural income volatility has become a major hurdle for Irish farmers and policymakers to overcome in their drive to increase investment, production and ultimately income in the sector. This paper studies data from 927 farms in the Teagasc National Farm Survey between 2005 and 2013, the first 9 years of the decoupled subsidy era. The primary income support for European farmers, the single farm payment (SFP), is analysed in the context of its relationship with market income risk, i.e. farm income excluding subsidies. Detrended measures of market income variability are regressed on a large set of control variables. The findings suggest that the amount of SFP received by farmers has a strong and statistically significant relationship with agricultural income volatility.
\end{abstract}

Keywords: Single farm payment, Agricultural policy, Income risk, Risk management, Farm assets

JEL classifications: D22, G320, Q12, Q18

\section{Background}

The European Union has throughout its history, intervened in agricultural markets through the European Common Agricultural Policy (hereinafter "CAP"), which began in 1958 as one of the original core policies of the European Community (EC) (ECPA 2013). Much of this support is directed to farmers as direct payments (DP). These payments are an effort to stabilise and increase farm income while sustaining farm businesses and the agricultural goods and services that they provide. As farmers around the world face climate change and competitive global markets, farm incomes have become increasingly unstable (Di Falco et al. 2014). In this context, it is important to analyse the relationship between DP and the variability of market incomes (i.e. farm incomes excluding the DP) for the Irish case. A well-targeted DP policy can assist those farms which are inherently more vulnerable to high variability in market incomes. At the same time, the DP can incentivize farmers towards riskier behaviour than would otherwise be the case and these unintended consequences must be addressed in any economic analysis of the relationship between DP and farm income variability (Capitanio and Adinolfi 2009).

Volatility in Ireland's agricultural sector has become a key issue for stakeholders across the industry (O'Connor and Keane 2011; O'Donoghue and Hennessy 2015). The 
rise in farm income volatility is not confined to any one farming system (Hynes and Hennessy 2012). The increased volatility of milk output prices and dairy farm incomes has, however, received the most attention (McDonald et al. 2014; Loughrey et al. 2015). European farmers, researchers and policy makers are preparing for continued price and income volatility into the future (Assefa et al. 2015; El Benni and Finger 2013). This raises a few interesting questions which must be answered if income variability is to be moderated for Irish farmers. Where does the increasing risk in Irish agriculture stem from? What are the implications of a persistently volatile farming environment? Which tools can we utilise to manage and adapt to risk while preserving the sustainability of Irish farms?

The purpose of this study is to build towards answers to these vital questions. In particular, we focus our attention on the potential relationship between decoupled farm payments ${ }^{1}$ and the variability of market incomes. Decoupled farm payments can reduce the overall farm income variability as these payments provide a more stable income source relative to income gained through market activities (Severini et al. 2016b). This study adds to the body of literature which questions the extent to which the so-called "decoupled payments" are truly decoupled from production decisions (Capitanio and Adinolfi 2009; Femenia et al. 2010; Howley et al. 2012; Finger and Lehmann 2012). ${ }^{2}$

In the context of the potential relationship between decoupled payments and risk management decisions, Hennessy (1998) concluded in a US study that the term "decoupled" can be misleading as both the wealth effect and the presence of risk aversion can ensure that decoupled payments affect production decisions. Indeed, Finger and Lehmann (2012) found among Swiss farmers that DP have a negative effect on the demand for hail insurance as a risk management strategy. Similarly, Koundouri et al. (2009) found that decoupled payments significantly altered the risk attitude of farmers in Finland after European Union accession. The literature has not always, however, identified a significant relationship between decoupled payments and risk attitudes or risk management decisions (Serra et al. 2011). It is therefore an empirical matter as to whether or not a relationship exists between decoupled payments and farm income risk in a particular context.

In investigating the origins of the recent increase in commodity price risk exposure to farmers, there are some explanations including the role of macroeconomic forces (Karali and Power 2013) and monetary policy action and communication (Hayo et al. 2012). In microeconomic theory, the weakness of short-term production and consumption elasticities in responding to economic shocks are cited as contributory factors (Gilbert 2006; Gilbert and Morgan 2010). Food producers are particularly vulnerable to commodity price risk as they must commit resources for the duration of a production cycle whereas consumers may have the opportunity to switch their consumption patterns in the short run (Sandmo 1971; Bellemare 2015). In developed countries, the exposure of consumers to commodity price risk is therefore usually considered less problematic than the exposure of farmer producers. Barrett and Bellemare (2011) have concluded that from a consumer perspective, "the world does not necessarily face a price volatility problem. It faces a high food price problem".

In the next section, we provide some detail on the policy background and in particular the efforts of European policymakers to address farm income variability. We follow this with a description of the theoretical relationship between DP, farm 
assets and farm income variability. This is followed by an empirical analysis of farm income risk in Ireland from decoupling in 2005 to 2013. The econometric analysis highlights the relationship between European single farm payment subsidies and the market income risk of farmers. While the single farm payment is seen "...as an important cushion against commodity price volatility" (DAFM 2015), the data suggests that high direct subsidy payments are actually associated with higher market income risk.

\section{Policy background}

To avoid the negative impacts associated with high farm income variability, producers and policymakers internationally have developed a number of risk management strategies. Research has found that these strategies vary widely in terms of efficacy and may have actually served to increase income risk in the long term. Mishra and Sandretto (2002) examined the variability in net farm income in the USA since the development of farm price and income support programmes in the 1930s and conclude that variability did not fall between the mid-1930s and the end of the twentieth century and that the increase in non-farm income played an important role in reducing overall household income variability.

The European Union policy interventions have included a range of incentives including consumption subsidies, intervention prices, price floors, export refunds, import tariffs, quotas for food products, precautionary savings and crop insurance subsidies (Jongeneel et al. 2010; ECPA 2013). One of the objectives of the Common Agricultural Policy (CAP), as provided by Article 39 in the 1957 Treaty of Rome, is "to ensure a fair standard of living for the agricultural community, in particular by increasing the individual earnings of persons engaged in agriculture". Food market stabilisation has been identified as a key to reaching these goals of CAP (ECPA 2013). The CAP expenditures now account for approximately $40 \%$ of the European Union budget (European Commission 2016).

The CAP policies dampened downside market risk but were found to significantly boost the risk appetites of producers (Serra et al. 2011; Sckokai and Moro 2009). Matthews (2010) concludes that prior to 2005, the CAP successfully insulated EU domestic prices from the volatility of the world market but the price stability interventions became "increasingly intertwined with and dominated by" a motivation to simply transfer income to the EU farm sector. The associated "budget costs" and "environmental criticisms" motivated policymakers towards reforming agricultural policy supports and deciding to largely decouple farm subsidies from production in the 2003 reforms, which became enacted in 2005 (Capitanio and Adinolfi 2009).

These reforms essentially involved a replacement of price supports with direct subsidy payments based on historical production. Since DP do not directly affect farmers' price uncertainty as price supports do, these payments theoretically have a less distorting effect on production and risk decisions (Sckokai and Moro 2009). DP have the potential, however, to increase farmers' wealth, which tends to slightly increase the risk appetite over the long term (Kazukauskas et al. 2013). Decoupled subsidies ought to reduce income variability as they are more predictable and not dependent on production (Fidrmuc et al. 2013) cited in (Kazukauskas et al. 2013). However, it is this very predictability that makes decoupled payments attractive as collateral to financial institutions (Rizov et al. 2013). This gives farmers the opportunity to increase debt levels and increase production 
which can ultimately lead to higher income risk. DP also act as a type of income insurance for farmers which crowds out other "natural" risk management strategies such as diversification and may induce less risk averse behaviour (El Benni et al. 2012; Falco et al. 2014).

The CAP has undergone numerous reforms and policy regimes since its inception. In a study of the relationship between the European Union policy regime and farm income variability among a subset of arable farms in Germany, Feil et al. (2014) found that farm income variability increased from the mid-1980s onwards and suggested that this could be attributed to "rising price volatility in markets for agricultural commodities" in addition to the relevant policy reforms. Mary (2013) found single farm payments to be less investment distorting than counter-cyclical insurance payments among crop farms in France. In a study by Serra et al. (2011), decoupled payments were found to have negligible effects on risk preferences in the short run among a group of Kansas farmers. Severini et al. (2016a) investigated the farm income variability among Italian farms between 2003 and 2012 and found that income variability increased during this time but with significant differences among farm groups in the levels and evolution of income variability. Severini et al. (2016a) conclude that the increasing level of farm income variability supports the idea of introducing risk management tools within the CAP toolbox.

Research suggests that income variability is growing overall but that each source of risk needs to be addressed individually. Farm type, size, and location are major factors in the risk burden that a farm carries, and these elements also impact the farm's ability to manage risk (Severini et al. 2016b). High levels of income risk or improperly structured subsidy and risk management policies may cause farmers to reduce their provision of social, environmental and economic goods (Capitanio and Adinolfi 2009). Farm families may restrict their consumption impacting negatively on their welfare. Investment may also be reduced, which can hurt productivity in the long term (O'Toole et al. 2014). Fortunately, farmers and policymakers have multiple methods at their disposal to mitigate income risk and the negative consequences associated with it. Although farmers have many ways of managing income risk independently, these strategies may be dependent on factors such as the production system, labour market or financial situation of the individual farm. Government efforts to smooth farm incomes can often be costly and may induce riskier farmer behaviour in the long run. As farm income volatility increases, policies must be structured to effectively manage short run and long run while efficiently utilising limited government funds.

\section{Methods}

\section{Theory and hypothesis}

The theoretical framework for this paper is grounded on expected utility theory under a mean-standard deviation utility function. As in the case of Boyle et al. (2005), we assume that farm incomes and farm assets follow a log-normal distribution $v\left(\mu^{*}, \sigma^{*}\right)$ where $\mu^{*}$ is the mean of the random variable and $\sigma^{*}$ is its standard deviation. This research is not focused on delivering precise estimates of relative or absolute risk aversion. The focus is instead placed on the possible relationship between a particular public policy and farm income risk. Much of the research in relation to farmer risk aversion points to farmers being risk averse and therefore willing to make trade-offs between risk and expected farm profits (see, for example Chavas and Holt 1996; Picazo-Tadeo and Wall 2011; Menapace et al. 2013). 
The single farm payment is a non-labour source of income thereby conferring a wealth advantage rising with the size of payment (Femenia et al. 2010). The single farm payment is a liquid source of income and is therefore clearly distinct from other forms of wealth such as land and buildings. In the farm risk literature, it is sometimes assumed, however, that income and wealth have equal weight in the argument of the utility function for risk decisions. For instance, Hardaker et al. (2004) assume that farmers make risk decisions under full asset integration. This appears to be a very strong assumption given that farm assets are typically of a much less liquid form relative to farm income. It therefore appears more reasonable to expect that farmers operate under partial asset integration where the farm assets are less influential than farm income in affecting risk appetite and therefore risk decisions.

Given the asset increasing nature of DP, we interpret our findings with reference to alternative degrees of asset integration including full asset integration - expected utility theory (FAI-EUT) where money amounts relating to farm wealth and farm income have equal weight in the argument of the utility function. In particular, we consider the likelihood of partial asset integration - expected utility theory (PAI-EUT) where farm wealth enters the utility function in a lower proportion to farm income. We also consider the possibility of non-asset integration - expected utility theory (NAI-EUT) where the farm wealth plays no part in the utility function and therefore no role in determining the decisions relating to farm income risk.

Given the illiquid nature of farm wealth in Ireland, we may therefore anticipate that farm income and farm wealth enter the utility function in different proportions to one another, i.e. partial integration. ${ }^{3}$ In such circumstances, there is likely to be a relationship between wealth and the income risk of the farm but not in equal proportions. Cox and Sadiraj (2006) describe a model of expected utility of initial wealth and income under the following:

$$
\int u(w, y) d G=E_{G}(u(w, y))
$$

where $G$ is an integrable probability distribution function and $u$ can be considered as a utility function of initial farm wealth $w$ and farm income $y$. Andersen et al. (2011) refer to this as the PAI-EUT model as it allows for partial asset integration. The model allows for the polar opposite cases of FAI-EUT and NAI-EUT. Under FAI-EUT, the utility is due simply to the sum of initial farm wealth and farm income where $u(w, y)$ $=v(w+y)$. Under NAI-EUT, the utility is entirely due to the farm income flows and $u$ $(w, y)=\varphi(y)$.

At present, the primary income protection policy for Irish farms is the wealth-inducing decoupled single farm payment. Enjolras et al. (2014) suggested that DP may have a slight positive association with income risk for crop farms in Italy, but this relationship was not statistically significant in France. French farms may have used the additional payment income as a way to shift down Blank's (2001) "farming food chain" to less risky production systems. Smaller Italian farms may have less flexibility in their production systems. Irish farms also tend to be small and have limited opportunities for expansion or transition to different production systems on the "farming food chain" given the climatic limitations of Ireland. 
The relationship between risk and decoupled payments may be linked to the wealth effect of annual transfer payments (Kazukauskas et al. 2013). Rizov et al. (2013) also note that steady payments may increase farmers' access to, and preference for, financial goods, therefore increasing financial risk (Rude 2008). Others may use single farm payments to reduce their amount of buffer savings or time spent in off-farm work. The SFP may also result in lower risk for less entrepreneurial "entitlement farmers" who use subsidies to maintain their incomes with less business risk (Thorne and Hennessy 2007). These studies highlight the debate over the risk effects of decoupled payments, but their conclusions are not necessarily applicable to the largely livestock based agricultural system in Ireland. Consequently, hypothesis H1 needs to be empirically tested in the Irish context.

H1 (income risk): Decoupled single farm payments as part of the Common Agricultural Policy are significantly associated with farm-level market income risk in Ireland.

H2 (farm assets): Farm assets are integrated into the decision-making of farmers in relation to farm income risk. This can be evidenced from a significantly positive econometric relationship between the size of the farm assets and the income risk of the farm.

\section{Data and methodology}

To assess the income variability of individual Irish farms, the Teagasc National Farm Survey (NFS) dataset is used. Since 1972, the NFS has collected detailed financial and production data from farms as part of the EU Farm Accountancy Data Network. Between 1000 and 1200 farms are randomly sampled each year to represent 110,000 farms in Ireland. Due to attrition and to maintain representivity, about 15 to $20 \%$ of surveyed operations are cycled out of the NFS annually.

Variability is measured as the standard deviation of gross market income from the multi-year trend over the 9-year study period. Nine years was selected as the appropriate study period in order to limit attrition loss. This methodology is similar to that of Enjolras et al. (2014). Poon and Weersink (2011) note that the use of gross income eliminates the problems of negative incomes and avoids distortions caused by differences in overhead (fixed) costs ("Appendix"). In many cases, farm overheads are difficult to differentiate from household fixed costs. For these reasons, the use of gross income has been used in a number of agricultural income risk studies such as Mishra and Goodwin (1998) and Jetté-Nantel et al. (2011). Gross market income includes product sales less overhead costs. Market income does not include decoupled single farm payments or other subsidies such as environmental payments. The absolute value of decoupled subsidies was used as in Enjolras et al. (2014) rather than the ratio measure used by Severini et al. (2016b). Since many Irish farmers also have off-farm incomes, the absolute value of DP is of more interest than the proportion of farm income derived from subsidies. This study differs from the work of Enjolras et al. (2014) as it analyses a sample of primarily livestock farms which have a different risk profile than the field crop-based agriculture of France and Italy. This analysis also does not include crop insurance as Irish farmers do not have access to farm revenue insurance products.

Table 1 displays summary statistics for the sample which includes farms observed during at least six of the nine from 2005 to 2013. In all, 927 farms provided data on an average of 8.2 occasions. By controlling for linear income trends over the 8-year period, 
Table 1 Descriptive statistics

\begin{tabular}{lll}
\hline Variable & Mean & Standard deviation \\
Detrended standard deviation of gross market output & 11,842 & 12,287 \\
Initial decoupled subsidies ( $€)$ & 21,787 & 15,547 \\
Change in decoupled subsidies (€) & -351 & 7184 \\
Mean coupled subsidies (€) & 2286 & 2880 \\
Mean gross output & 70,924 & 78,844 \\
Farm characteristics & Mean & Standard deviation \\
Mean livestock units per hectare & 1.34 & 0.60 \\
Mean daily concentrates per L.U. (kg) & 1.45 & 1.23 \\
Mean crop protection cost & 1120 & 3476 \\
Mean fertiliser cost & 6572 & 7196 \\
Mean farmer age & 53.9 & 11.0 \\
Mean farmed area (ha) & 56.7 & 43.1 \\
Off-farm work & Percent & Observations \\
Initial off-farm job, farmer & 27.1 & 252 \\
Initial off-farm job, spouse & 36.8 & 341 \\
Initial farm system & Percent & Observations \\
Cattle rearing & 21.6 & 200 \\
Cattle and other & 18.4 & 171 \\
Dairy & 26.9 & 249 \\
Dairy and other & 13.3 & 123 \\
Sheep & 11.2 & 104 \\
Tillage & 8.6 & 80 \\
\hline
\end{tabular}

we can account for farms in deliberate expansion or decline. Risk management policies should not restrict the abilities of farms to expand or contract voluntarily but should help farms to manage year to year income swings (Finger and El Benni 2014).

The independent variables use the mean or initial values for each farm over the sample period such that each farm is represented by one observation. The key independent variable of interest is the initial value of decoupled payments and the farm-level change in payments over the sample period. As evidenced from Table 1, the decoupled subsidies contribute significantly to family farm income. Compared to other European countries, total per hectare payments to Irish farms are similar to those of Italian farms and are above French payment levels. Coupled subsidies include livestock and tillage subsidies which became increasingly rare over the 2005 to 2015 observation period. Gross output includes the market value of all agricultural production. At 1251 euros per hectare, Irish gross farm output is below the mean levels of French and Italian farms analysed by Enjolras et al. (2014).

Farm-level control variables include land farmed and rented in as well as stocking rate, concentrates fed and crop protection costs. Livestock density is significantly higher than the EU-27 average (Eurostat 2015). Crop protection cost is very low compared to the sample of French and Italian farms used by Enjolras et al. (2014). This highlights the importance of livestock relative to tillage farming in Ireland. Mean farm size is small but is similar to the mean size of the Italian farms in the sample used by Enjolras et al. (2014). Even though farm sizes are small in Ireland, land values are among the highest in Europe making the land wealth of Irish farmers significantly higher than that 
of Italian or French farmers (Keith 2013). A significant number of farmers and their spouses were employed off the farm during the study period. In Table 1, the off-farm employment statistics refer to the initial condition when the farm first entered the sample. Table 1 shows that $40 \%$ of the sampled farms were primarily involved in beef production. Of these farms, just over half were suckler farms producing young beef animals while the remainder were primarily finishing farms. Specialist dairy farms are the single largest farm system, encompassing more than one quarter of the sample. This sample reflects the agricultural industry of Ireland which is predominantly livestock based. Like Enjolras et al. (2014), this data does not include information on farmers' use of forward contracting or spread selling; however, these options are limited to tillage and dairy farmers and were not widely used during the study period. For a detailed picture of farm income risk in Irish tillage farming and the potential role of forward contracts in managing this risk see Loughrey et al. (2016). Unlike Enjolras et al. (2014), this data does not include savings or debt related information.

To analyse the income variation among farms in this sample, this model adapts the methodology developed by Enjolras et al. (2014) and uses the standard deviation of farm market income as the key dependent variable. This model differs from Enjolras et al. (2014) by using the standard deviation from stationary, detrended market income rather than mean market income. This measure of variability accounts for the endogenous variability of farms that were purposefully expanding or shrinking during the 2005 to 2013 observation period. The natural log of standard deviation is used to normalise the distribution which is skewed by a few highly variable operations.

$$
\operatorname{Ln}\left(\sigma Y_{c i}\right)=\beta \operatorname{Ln}\left(Y_{d i}\right)+\beta \operatorname{Ln}\left(\bar{Y}_{c i}\right)+\beta X_{i t}+\alpha+\varepsilon_{i t}
$$

where $\sigma Y_{c i}$ stands for the standard deviation of market income earned by farm $i$ across all of farm $i$ 's observations, $Y_{d i}$ stands for the mean level of income from decoupled payments, $d$, for each farm over the sample period and $X_{i t}$ symbolises the set of additional covariates which control for coupled subsidy payments and farm characteristics. The term $\bar{Y}_{c i}$ represents the mean market income or alternatively output of farm $i$ during the period. We apply the mean market output in order to account for scale effects which may not be adequately captured by variability between farms in the mean market income or land area.

\section{Results and Discussion}

Table 2 shows the results of the model for the full sample and for the four individual farm types. Income variation was significantly associated with initial decoupled subsidy payments for beef cattle and sheep farms, but this effect was insignificant for dairy and tillage farms. Dairy and tillage farmers in Ireland are far more profitable than cattle and sheep farmers and are thus less reliant on direct payments as an income source (Hennessy and Moran 2015). Since Irish cattle and sheep farmers derive nearly all of their profit from direct payments, it makes sense that initial direct payments dictate the amount of income risk these farmers can take on (Hennessy and Moran 2015).

In all of the models, there is a strong positive relationship between increases in decoupled farm payments and market income variation. These results appear to be intuitive given that changes in decoupled payments can be accompanied by changes to the farm size thereby impacting on the farm income variability over the period. In 
Table 2 Standard deviation of market income on Irish farms

\begin{tabular}{|c|c|c|c|c|c|}
\hline Variable & Full sample & Dairy only & Cattle & Sheep & Tillage \\
\hline Initial decoupled subsidies $(€ 10,000)$ & $0.10^{* * *}$ & 0.01 & $0.10^{* * *}$ & $0.19^{* * *}$ & 0.05 \\
\hline Change in decoupled subsidies $(€ 10,000)$ & $0.13^{* * *}$ & $0.09^{* *}$ & $0.10^{* * *}$ & $0.28^{* * *}$ & $0.15^{* *}$ \\
\hline Log of coupled subsidies & $0.02^{* *}$ & 0.03 & $0.03^{* *}$ & 0.07 & 0.03 \\
\hline Log of gross output & $0.53^{* * *}$ & $0.63^{* * *}$ & $0.50^{* * *}$ & $0.31^{* * *}$ & $1.06^{* * *}$ \\
\hline Initial land owned (100 ha) & $0.13^{* *}$ & $0.39^{* * *}$ & 0.18 & 0.03 & 0.12 \\
\hline Initial land let out (100 ha) & 0.17 & -0.15 & 0.45 & -0.09 & -0.81 \\
\hline Initial land rented in (100 ha) & $0.24^{* * *}$ & $0.50^{* * *}$ & 0.18 & 0.50 & 0.38 \\
\hline Change in land owned (100 ha) & 0.06 & -0.09 & 0.04 & 0.01 & $1.69^{* *}$ \\
\hline Change in land let out (100 ha) & -0.25 & 1.03 & -0.72 & -0.59 & -1.19 \\
\hline Change in land rented in (100 ha) & 0.07 & 0.02 & 0.08 & -0.05 & 0.07 \\
\hline Livestock units per hectare (100 ha) & $-0.07^{*}$ & -0.06 & 0.01 & -0.13 & -0.12 \\
\hline Daily concentrates per L.U. (kg) & 0.01 & -0.03 & 0.02 & 0.01 & -0.04 \\
\hline Crop protection cost $(10,000 \mathrm{~s} €)$ & $0.13^{*}$ & 0.24 & $0.29^{*}$ & -0.03 & 0.26 \\
\hline Fertiliser cost $(10,000 \mathrm{~s} €)$ & -0.03 & -0.07 & -0.08 & 0.01 & $-0.44^{* *}$ \\
\hline Mean farmer age & -0.01 & $-0.04^{* *}$ & 0.01 & -0.00 & $-0.03^{*}$ \\
\hline Mean farmer age squared & 0.00 & $0.00^{* *}$ & -0.00 & 0.00 & $0.00^{* *}$ \\
\hline Farmer off-farm job & 0.02 & $0.10^{*}$ & 0.01 & -0.07 & 0.16 \\
\hline Spouse off-farm job & 0.01 & 0.03 & -0.04 & 0.12 & $0.21^{*}$ \\
\hline Cattle & $-0.23^{* * *}$ & & & & \\
\hline Sheep & $-0.18^{* * *}$ & & & & \\
\hline Tillage & $-0.33^{* * *}$ & & & & \\
\hline Constant & $-5.74^{* * *}$ & $-6.02^{* *}$ & $-6.28^{* * *}$ & $-4.51^{* * *}$ & $11.00^{* * *}$ \\
\hline$N$ & 927 & 249 & 494 & 104 & 80 \\
\hline$R^{2}$ & 0.80 & 0.80 & 0.76 & 0.67 & 0.84 \\
\hline
\end{tabular}

******, ${ }^{*}$ The corresponding coefficients are significant at 1, 5 and $10 \%$ level, respectively

terms of the initial size of the payments, the decoupled subsidy effect is found to be significantly positive for the full sample but is not found to be significant for dairy or tillage farms. This suggests that subsidies are less important in altering the risk profile of the more market-oriented, higher income dairy and tillage farms. Coupled subsidy payments are much smaller and have a much weaker effect on income risk overall. High gross output is also correlated with high income variability. This effect is particularly strong for tillage farms which may use their higher market revenue as a buffer against income variability.

The data suggests that certain farm inputs have a significant effect on market income risk. Farms with larger areas of owned and rented land tend to have higher income variability overall. Larger investments in land may be associated with a larger risk appetite which also translates into large year to year changes in income. Land owned is a source of wealth. In the case of dairy farms, this appears to be positively associated with farm income risk. This result may indicate some degree of partial asset integration into the risk decision-making process. Rented land is a very small proportion of farmland, but changes in rented land had a large effect on income risk for tillage farms. Stocking rate had a small negative effect on income variation overall which suggests that intensive grassland management may be associated with effective risk management. 
Although operator age is not significantly associated with income risk over the full sample, it is a significant factor for dairy and tillage farms. The quadratic effect suggests that the youngest and oldest farmers in the sample have the highest income risk. Younger farmers may be actively taking on new risks as they enter the market while older farmers may be less able to manage risk on their own. While the signs are somewhat expected, we find that off-farm work only has a significant impact on income risk for dairy farmers. The proceeds of an off-farm job could be used as a hedge against on-farm income risk and off-farm work may also mean less time for on-farm risk mitigation. Different production systems also have different levels of income variability. At the margin, dairy farms have significantly more income variation than all other farm types.

This comparative model suggests that farms most associated with volatile incomes tend to be high-income dairies, with large and increasing single farm payments. It also shows us that the main sources of risk for dairy farms are not substantially different than those of other farm types. The $\mathrm{r}$-squared for the individual farm type models are only slightly below the $\mathrm{r}$-squared for the full sample model. This suggests that multi-year standard deviation is an appropriate variability measurement even when a single farm type with a smaller sample size is analysed.

These results remained robust when absolute deviation of income was used as the dependant variable and also when farms observed less than nine times were excluded from the sample.

\section{Conclusions}

To test whether decoupled subsidy payments increase income risk on farms, we model income variability over 9 years for 927 farms in Ireland. This model supports the argument that decoupled payments and market income risk are closely and positively related. Even after correcting for individual level time trends and a variety of farm characteristics, these results remain robust. The positive relationship between decoupled payments and income risk in Irish farms is similar to the payments and risk relationship found by Enjolras et al. (2014) for Italian farms. The small farm sizes and relatively large payment levels in both Italy and Ireland contribute to their similar risk patterns. This model also paints a picture of Irish farms that are likely to have highly variable incomes. These farms are likely to be large dairy farms with large outputs in addition to large and increasing subsidy payments and lower stocking rates.

The findings of this study can be interpreted in a number of different ways. One may conclude that the positive association between decoupled payments and income risk is welcome as decoupled payments appear targeted towards farms with a higher risk profile. However, under an expected utility framework, the results are somewhat concerning. In this framework, the positive relationship suggests that decoupled payments induce farmers to take on greater risks in their market activities and that those farms with the largest payments are given an advantage in terms of their scope to manage market risks. The results suggest that some degree of asset integration is present and that the value of the decoupled payments influence risk management behaviour.

While large decoupled subsidy payments insulate farmers against instances of low income, they utilise significant amounts of public wealth to accomplish this. Our results 
indicate that land ownership is positively associated with market income risk and therefore contribute to risky decision-making. Meanwhile, the private assets of farmers, which on average are more than five times greater than Irish households overall, are substantially underutilised (Thorne et al. 2015; Central Statistics Office 2015). Ultimately, this system does not incentivise operators to manage risk. Indeed, the increased wealth and cash flow that the decoupled payments offer may be spurring farmers towards riskier business models. To use the example of the dairy industry, subsidies are unlikely to encourage the "better before bigger" policy which is seen as a key to dairy farm resilience (Boyle 2015). This project serves to provide further empirical evidence that single farm payments, under their current structure, are associated with increased risk over a multi-year period.

As the structure of the Common Agricultural Policy evolves, policymakers will need to take a hard look at decoupled payments. Irish farm income data from 2005 to 2013 suggests that subsidy payments are a very costly method of moderating farm income downturns. If supporting consistent farm incomes is truly a goal of the CAP, then the subsidy system may need to be overhauled. This is of particular concern given the increasing volatility pressures due to climate change and globalisation. Future risk management tools should do more than simply transfer wealth to farmers but should incentivise farmers to take control of the many sources of risk that they face.

The body of literature on the risk impacts of decoupled payments has plenty of room for expansion. Part of the reason for this is that the decoupled era is currently only a decade old. As this policy ages, more data will become available and should be thoroughly analysed to determine the long-term effects of decoupling on the risk behaviours of farmers. One of the limitations of this study is that it only includes the decoupled era which began in 2005. More detailed research in the area of agricultural income risk could look back to the DP era of the 1990s, or perhaps even earlier, to see what may have caused payments to start flowing to more volatile operations. This pattern continued as Ireland distributed payments based on the historical model, but more study is needed to determine the effects of payments distributed under regional or flat payment models. As farm income volatility increases and policies continue to evolve, analyses of other systemic risk factors not included in this paper are likely to be highly valuable. Climate change, policy evolution and changing farm asset values are just a few of these factors.

\section{Endnotes}

${ }^{1}$ Decoupled payments include single farm payments and disadvantaged area payments.

${ }^{2}$ While these studies found some relationship between decoupling and production decisions, a number of studies have found little or no significant relationship (Goodwin and Mishra 2005; Weber and Key 2012; O’Neill and Hanrahan 2012; Chambers and Voica 2016).

${ }^{3}$ Irish farmers attach a non-economic value to the ownership of agricultural land and that market sales of agricultural land are relatively low as a proportion of agricultural area. It therefore seems reasonable to anticipate that the wealth attached to agricultural land is illiquid and cannot be readily accessed. In addition, farmers are reluctant to rent out land and therefore accrue the monetary benefits of rental agreements. 


\section{Appendix}

\section{Detrending coupled gross income}

Correcting for the linear time trend allows us to focus on income as a stationary variable and ignore variability caused by long-term trends in income. Ordinary least squares regressions of individual farm income from 2005 to 2013 adapted from Richardson et al. (2000) are used to test for significant time trends. Equation 3 below expresses the market income, $Y$, of an individual farm $i$ in year $t$. Here, income is a function of the observation year times a trend coefficient plus a constant and error term. If the trend coefficient is determined to be statistically significant ( $p$ value less than 0.05), then $Y_{i t}$ is used as the predicted farm income for each year.

$$
\hat{Y}_{\text {it }}=\hat{a}+\hat{b}\left(\operatorname{Trend}_{i t},\right)+\hat{e}
$$

If the trend coefficient is insignificant, then the mean income level, $\bar{Y}_{i t}$, is used as the predicted farm income for each year as expressed in Equation 4.

$$
\hat{Y}_{i t}=\bar{Y}_{i t}
$$

Farm incomes were only detrended if their linear time trend was significant at less than the $p=0.05$ significance level. About $20 \%$ of the 927 sampled farms met this criterion. This group was approximately equally distributed between positive and negative income trends, but specialist dairy farms were more likely to have a significant positive trend. Although using a benchmark significance level is an imperfect method of detecting time trends, failing to correct for farm-level time trends has its own costs. Non-detrended data would be more likely to exaggerate the endogenous variability of farms which are steadily shrinking or expanding over time.

\section{Calculating historic model decoupled payments}

Decoupled DP in Ireland were calculated using the historic model with minimal coupled payments (DAF 2004). Other nations, such as Germany, moved towards a regional per hectare payment while France opted to retain many of its coupled payments (EC 2010). The historic model averaged the number of subsidy eligible animals and hectares for each farm in the years 2000, 2001 and 2002. Those averages were then multiplied by the 2002 payment rate in the form given by Equation 5 below (O’Neill and Hanrahan 2012).

$$
\mathrm{SFP}=\sum_{i=1} \bar{H}_{i} \times P_{i}+\sum_{j=1} \bar{N}_{j} \times P_{j}
$$

Here, the single farm payment, SFP, is a function of acreage and livestock payments. The sum of average hectares, $\bar{H}$, eligible under scheme $i$, multiplied by the 2002 payment rate, $P_{i}$, is added to the sum of average animals, $\bar{N}$, eligible under scheme $j$, multiplied by the 2002 payment rate $P_{j}$.

The level of single farm payment received by farms each year is not normally distributed. While no farm receives negative payments, outlier farms exist which receive extremely high payments and these skew the distribution to the right. 


\section{Results using farm assets}

Table 3 includes the results of the model when farm assets are used to control for scale effects instead of land area. The farm assets variable is the sum of farmer-reported values for land, buildings, machinery, and livestock. These results are broadly aligned with the results of the land area model. Once again, we see that decoupled payments are significantly associated with income variability. Farm assets appear to be associated with increased income risk, at least for cattle farms where there is wide variation in asset levels between operations. This likely speaks to the illiquid nature of farm assets in Ireland. Due to this illiquidity, decoupled subsidies and farm revenue are more likely to be used as buffers against income volatility than assets.

Table 3 Standard deviation of market income on Irish farms (farm wealth model)

\begin{tabular}{|c|c|c|c|c|c|}
\hline Variable & Full sample & Dairy only & Cattle & Sheep & Tillage \\
\hline Initial decoupled subsidies $(€ 10,000)$ & $0.11^{* * *}$ & 0.02 & $0.11^{* * *}$ & $0.25^{* * *}$ & 0.06 \\
\hline Change in decoupled subsidies $(€ 10,000)$ & $0.14^{* * *}$ & $0.09^{* * *}$ & $0.11^{* * *}$ & $0.29^{* * *}$ & $0.15^{* *}$ \\
\hline Log of coupled subsidies & $0.02^{* *}$ & 0.02 & $0.03^{* *}$ & 0.06 & 0.03 \\
\hline Log of gross output & $0.51^{* * *}$ & $0.66^{* * *}$ & $0.45^{* * *}$ & $0.34^{* * *}$ & $1.00^{* * *}$ \\
\hline Log of total farm assets & $0.07^{* *}$ & 0.08 & $0.14^{* * *}$ & -0.04 & -0.00 \\
\hline Livestock units per hectare (100 ha) & $-0.09^{* * *}$ & $-0.16^{* * *}$ & -0.02 & -0.13 & -0.00 \\
\hline Daily concentrates per L.U. (kg) & 0.01 & -0.02 & 0.03 & -0.01 & -0.04 \\
\hline Crop protection cost $(10,000 \mathrm{~s} €)$ & $0.19^{* * *}$ & 0.06 & $0.30^{* *}$ & -0.28 & $0.34^{*}$ \\
\hline Fertiliser cost $(10,000 \mathrm{~s} €)$ & -0.01 & -0.00 & -0.05 & 0.08 & $-0.37^{* *}$ \\
\hline Mean farmer age & -0.01 & $-0.04^{* *}$ & 0.01 & -0.01 & -0.02 \\
\hline Mean farmer age squared & 0.00 & $0.00^{* *}$ & -0.00 & 0.00 & 0.00 \\
\hline Farmer off-farm job & 0.02 & $0.10^{*}$ & 0.02 & -0.04 & 0.21 \\
\hline Spouse off-farm job & 0.01 & 0.03 & -0.05 & 0.14 & $0.21^{*}$ \\
\hline Cattle & $-0.24^{* * *}$ & & & & \\
\hline Sheep & $-0.16^{* * *}$ & & & & \\
\hline Tillage & $-0.40^{* * *}$ & & & & \\
\hline Constant & $-5.75^{* * *}$ & $-6.58^{* * *}$ & $-6.28^{* * *}$ & $-4.55^{* * *}$ & $-10.60^{* * *}$ \\
\hline N & 927 & 249 & 494 & 104 & 80 \\
\hline$R^{2}$ & 0.80 & 0.79 & 0.76 & 0.66 & 0.81 \\
\hline
\end{tabular}

***,****The corresponding coefficients are significant at 1,5 and $10 \%$ level, respectively

\section{Abbreviations}

CAP: Common agricultural policy; DP: Direct payments of the CAP; FAI-EUT: Full asset integration - expected utility theory; NAI-EUT: Non-asset integration - expected utility theory; PAI-EUT: Partial asset integration - expected utility theory

Acknowledgements

The authors would like to thank Professor Cathal O'Donoghue for his advice on controlling for farm scale effects.

\section{Authors' contributions}

$J \mathrm{~L}$ coordinated the research and outlined the methodology, particularly the detrending of farm incomes. EK and $J$ together developed the econometric model. EK drafted the "Results" section. The other sections have been jointly drafted by the authors. Both authors have read and approved the final manuscript. 


\section{Publisher's Note}

Springer Nature remains neutral with regard to jurisdictional claims in published maps and institutional affiliations.

Received: 21 November 2016 Accepted: 20 April 2017

Published online: 12 May 2017

\section{References}

Andersen S, Cox J, Harrison G, Lau M, Rutstroem E, Sadiraj V (2011) Asset integration and attitudes to risk : theory and evidence, Working Paper. Durham University, Durham.

Assefa TT, Meuwissen MP, Lansink AGO (2015) Price volatility perceptions, management strategies, and policy options in EU food supply chains, agricultural markets instability: revisiting the recent food crises., p 178

Barrett C, Bellemare M (2011) The G-20's error: food price volatility is not the problem. Foreign Affairs, New York

Bellemare MF (2015) Rising food prices, food price volatility, and social unrest. Am J Agric Econ 97(1):1-21

Blank SC (2001) Producers get squeezed up the farming food chain: a theory of crop portfolio composition and land use. Rev Agric Econ 23(2):404-422

Boyle G (2015) The end of the beginning; how future dairy expansion will benefit the Irish economy. Speaking notes for the conference, Teagasc, Available at: https://www.teagasc.ie/media/website/about/our-organisation/Dairy_ Conference_End_of_Milk_Quota_Gerry_Boyle_Speech.pdf. Accessed 22 June 2016.

Boyle G, Conniffe D, McQuinn K (2005) A new mean standard deviation utility function and the behaviour towards risk of specialist Irish agricultural producers: 1988-1997 (no. 5/RT/05). Central Bank of Ireland.

Capitanio F, Adinolfi F (2009) The relationship between agricultural insurance and environmental externalities from agricultural input use: a literature review and methodological approach. New Medit 8(3):41-48

Central Statistics Office (2015) Household finance and consumption survey 2013. CSO, Dublin

Chambers RG, Voica DC (2016) "Decoupled" farm program payments are really decoupled: the theory Am J Agric Econ 99(3):773-782.

Chavas JP, Holt MT (1996) Economic behavior under uncertainty: a joint analysis of risk preferences and technology. Rev Econ and Stat 1:329-35

Cox JC, Sadiraj V (2006) Small-and large-stakes risk aversion: implications of concavity calibration for decision theory. Games and Econ Behavior 56(1):45-60

Department of Agriculture and Food (2004) The Single Payment Scheme: An Explanatory Guide, DAF. https://www. agriculture.gov.ie/media/migration/farmingsectors/crops/single_pay_sch.pdf. Accessed 21 August 2015.

Department of Agriculture, Food, and the Marine (2015) Food wise 2025, the report of the 2025 agri-food strategy committee, DAFM., https://www.agriculture.gov.ie/media/migration/foodindustrydevelopmenttrademarkets/agrifoodandtheeconomy/foodwise2025/report/FoodWise2025.pdf. Accessed 26 August 2015

European Commission, Agriculture and Rural Development Directorate General (2010) Overview of the implementation of DP under the CAP in member states no. 73/2009, EC.

European Commission (2016) CAP expenditure in the total EU expenditure-CAP post-2013: key graphs \& figures. http://ec.europa.eu/agriculture/cap-post-2013/graphs/graph1_en.pdf. Accessed 28 June 2016

European Crop Protection Association (2013) What is the common agricultural policy (CAP)? ECPA. http://www.ecpa. eu/regulatory-policy-topics/cap. Accessed 19 August 2015

El Benni N, Finger R, Mann S (2012) Effects of agricultural policy reforms and farm characteristics on income risk in Swiss agriculture. Agric Finance Rev 72(3):301-324

El Benni N, Finger R (2013) Gross revenue risk in Swiss dairy farming. J Dairy Sci 96(2):936-948

Enjolras G, Capitanio F, Aubert M, Adinolfi F (2014) Direct payments, crop insurance and the volatility of farm income. Some evidence in France and in Italy. New Medit 13(1):31-40

Eurostat (2015) Livestock density index. Livestock units per hectare, 1990-2007., http://ec.europa.eu/eurostat/tgm/table. do?tab=table\&init=1\&language=en\&pcode=tsdpc450\&plugin=1. Accessed 2 March 2015

Falco SD, Adinolfi F, Bozzola M, Capitanio F (2014) Crop insurance as a strategy for adapting to climate change. J Agric Econ 65:485-504

Feil JH, Musshoff O, Roeren-Wiemers T (2014) Farm level effects of policy reforms in Germany: first empirical evidence. J Policy Modeling 36(6):1036-1047

Femenia F, Gohin A, Carpentier A (2010) The decoupling of farm programs: revisiting the wealth effect. Am J Agric Econ 92(3):836-848

Fidrmuc J, Ciaian P, Pokrivcak J (2013) Credit constraints, heterogeneous firms and loan defaults. Annals Econ and Finance 14(1):53-68

Finger R, El Benni N, (2014) Alternative specifications of reference income levels in the income stabilization tool. In Agricultural Cooperative Management and Policy (pp. 65-85). Springer International Publishing Switzerland

Finger R, Lehmann N (2012) The influence of DP on farmers' hail insurance decisions. Agric Econ 43(3):343-354

Gilbert C (2006) Trends and volatility in agricultural commodity prices. Agricultural commodity markets and trade: new approaches to analyzing market structure and instability, pp 31-60.

Gilbert CL, Morgan CW (2010) Food price volatility. Philosophical Transactions of the Royal Society B: Biological Sciences 365(1554):3023-3034

Goodwin BK, Mishra AK (2005) Another look at decoupling: additional evidence on the production effects of direct payments. Am J Agric Econ 1200-1210.

Hardaker JB, Huirne RB, Anderson JR, Lien G (2004) Coping with risk in agriculture (No. Ed. 2). CABI publishing, Oxfordshire.

Hayo B, Kutan AM, Neuenkirch M (2012) Communication matters: US monetary policy and commodity price volatility. Econ Letters 117(1):247-249

Hennessy DA (1998) The Production Effects of Agricultural Income Support Policies under Uncertainty. American Journal of Agricultural Economics 80 (1):46-57.

Hennessy T, Moran B (2015) Teagasc National Farm Survey 2015 results. https://www.teagasc.ie/media/website/ publications/2016/Income-Estimates-2015.pdf. Accessed 21 Feb 2017 
Howley P, Breen J, Donoghue CO, Hennessy T (2012) Does the single farm payment affect farmers' behaviour? A macro and micro analysis. Intl J Agric Management 2(1):57-64

Hynes S, Hennessy T (2012) Agriculture, fisheries and food in the Irish economy. World Econ 35(10):1340-1358

Jetté-Nantel S, Freshwater D, Katchova AL, Beaulieu M (2011) Farm income variability and off-farm diversification among Canadian farm operators. Agric Finance Rev 71(3):329-346

Jongeneel R, Berkum SV, Bont CD, Bruchem CV, Helming J, Jager J (2010) European dairy policy in the years to come; quota abolition and competitiveness. Rapport-Landbouw-Economisch Instituut, (2010-017)

Karali B, Power GJ (2013) Short-and long-run determinants of commodity price volatility. Am J Agric Econ 95(3):724-738

Kazukauskas A, Newman C, Clancy D, Sauer J (2013) Disinvestment, farm size, and gradual farm exit: the impact of subsidy decoupling in a European context. Am J Agric Econ 95(5):1068-1087

Keith S (2013) Land markets \& land structures across Europe: agricultural land market data. Food and Agriculture Organization of the United Nations. $5^{\text {th }}$ International workshop on land market development and land consolidation - Skopje, 21-24 April. http://www.fao.org/fileadmin/user_upload/Europe/documents/Events_2013/ TAIEX/2.1_Keith_en.pdf. Accessed 7 Mar 2013

Koundouri P, Laukkanen M, Myyrä S, Nauges C (2009) The effects of EU agricultural policy changes on farmers' risk attitudes. Eur Rev Agric Econ 36:53-77

Loughrey J, Thorne F, Kinsella A, Hennessy T, O'Donoghue C, Vollenweider X (2015) Market risk management and the demand for forward contracts among Irish dairy farmers. Intl J Agric Management 4(4):173-180

Loughrey J, Thorne F, Hennessy T (2016) A microsimulation model for risk in Irish tillage farming. Intl J Microsimulation, 9(2):41-76

Mary S (2013) To which extent are counter-cyclical payments more distorting than single farm payments? Evidence from a farm household model. Eur Rev Agric Econ 40(4):685-706

Matthews A (2010) Perspectives on addressing market instability and income risk for farmers. Discussion paper no. 324, The Institute for International Integration Studies. Trinity College, Dublin, Ireland

McDonald R, Macken-Walsh Á, Pierce K, Horan B (2014) Farmers in a deregulated dairy regime: insights from Ireland's new entrants scheme. Land Use Policy 41:21-30

Menapace L, Colson G, Raffaelli R (2013) Risk aversion, subjective beliefs, and farmer risk management strategies. Am J Agric Econ 95(2):384-389

Mishra AK, Goodwin BK (1998) Income risk and allocation of labour time: an empirical investigation. Appl Econ 30(12): 1549-1555

Mishra AK, Sandretto CL (2002) Stability of farm income and the role of nonfarm income in US agriculture. Rev Agric Econ 24(1):208-221

O'Connor D, Keane M (2011) Empirical issues relating to dairy commodity price volatility. In: Methods to Analyse Agricultural Commodity Price Volatility. Springer, New York, pp 63-83

O'Donoghue C, Hennessy T (2015) Policy and economic change in the agri-food sector in Ireland. Econ and Soc Rev 46(2, Summer):315-337

O'Neill S, Hanrahan K (2012) Decoupling of agricultural support payments: the impact on land market participation decisions. Eur Rev Agric Econ 39(4):639-659

O'Toole CM, Newman C, Hennessy T (2014) Financing constraints and agricultural investment: effects of the Irish financial crisis. J Agric Econ 65(1):152-176

Picazo-Tadeo AJ, Wall A (2011) Production risk, risk aversion and the determination of risk attitudes among Spanish rice producers. Agric Econ 42(4):451-464

Poon K, Weersink A (2011) Factors affecting variability in farm and off-farm income. Agric Finance Rev 71(3):379-397

Richardson JW, Klose SL, Gray AW (2000) An applied procedure for estimating and simulating multivariate empirical (MVE) probability distributions in farm-level risk assessment and policy analysis. J Agric and Appl Econ 32(02):299-315

Rizov M, Pokrivcak J, Ciaian P (2013) CAP subsidies and productivity of the EU farms. Journal of Agricultural Economics 64(3):537-557

Rude J (2008) Production effects of the European Union's single farm payment. Canadian J Agric Econ/Revue canadienne d'agroeconomie 56(4):457-471

Sandmo A (1971) On the theory of the competitive firm under price uncertainty. Am Econ Rev 61(1):65-73

Sckokai P, Moro D (2009) Modelling the impact of the CAP single farm payment on farm investment and output. Eur Rev Agric Econ 36(3):395-423

Serra T, Goodwin BK, Featherstone AM (2011) Risk behavior in the presence of government programs. J Econometrics 162(1):18-24

Severini S, Tantari A, Di Tommaso G (2016a) The instability of farm income. Empirical evidences on aggregation bias and heterogeneity among farm groups. Bio-based and Appl Econ 5(1):63-81

Severini S, Tantari A, Di Tommaso G (2016b) Do CAP direct payments stabilise farm income? Empirical evidences from a constant sample of Italian farms. Agric and Food Econ 4(1):1-17

Thorne FS, Dillon E, Donnellan T, Hanrahan K, Hennessy TC, Kinsella A, Laepple D, McKeon M (2015) A review of the financial status of Irish farms and future investment requirements, Teagasc and Bank of Ireland. https://www. bankofireland.com/fs/doc/press-releases/boi-teagasc-investment-report.pdf. Accessed 23 June 2016.

Thorne FS, Hennessy TC (2007) Risk analysis and stochastic modelling of agriculture. Teagasc Rural Economy Research Centre: End of Project Report 5221. Teagasc Rural Economy Research Centre, Galway (2005)

Weber JG, Key N (2012) How much do decoupled payments affect production? An instrumental variable approach with panel data. Am J Agric Econ 94(1):52-66 